\title{
The Impact of the Higher Education and Science System on the Sustainable Development of Territories
}

\author{
Yu. Masalova ${ }^{1,2, *}$ \\ ${ }^{1}$ Novosibirsk State University of Economics and Management, Novosibirsk, Russia \\ ${ }^{2}$ Novosibirsk State Technical University, Novosibirsk, Russia \\ ${ }^{*}$ Corresponding author. Email: ymasalova@yandex.ru
}

\begin{abstract}
In modern conditions, the role of science and higher education, which should contribute to regional development, is significantly changing. The emphasis is on the formation of scientific and educational clusters in the Russian regions, which are designed to ensure the transfer of knowledge from the place of creation (science and higher education) to the production sphere, as a place of their application. In Russia, since 2011, in accordance with the Federal Target Program for the Development of Education, the task of ensuring the functioning of scientific and educational clusters in the regions of the country has been set. This approach is designed to ensure the solution of practical production tasks at the regional level, including through the training of specialists for the needs of enterprises in the region. These institutional transformations are designed to provide a direct impact on the socio-economic development of regions (territories). However, at present, an assessment of the possibility of creating and further effective functioning of such associations has not yet been given. The article will consider the prerequisites for the creation of scientific and educational clusters in Russian regions and make a forecast regarding their impact on the sustainable development of territories.
\end{abstract}

Keywords: higher education, scientific and educational cluster, region, university.

\section{NTRODUCTION}

Sustainable development of territories is impossible without improving the activities of organizations that operate in specific regions. Thanks to them, prerequisites are created for ensuring a certain quality of life of the population and opportunities for realizing the human potential of these territories. The prerequisites for territorial development are, first of all, geographical and climatic conditions. However, infrastructure features significantly affect not only the population density in Russian regions and migration processes, but also affect the prospects for economic development and the use of their natural resource potential. The issues of sustainable development of territories are currently being actively considered, so according to the search query for the phrase "sustainable development of territories" in the scientific electronic library (elibrary.ru) over 37 million publications are offered, which indicates a great interest in the problem on the part of researchers. In these works, the emphasis is primarily on the natural features of the regions, special attention is paid to the development of rural areas and tourist recreation, the territories of advanced socioeconomic development are considered separately, the role of the concept of sustainable development in the development of regions is determined, etc. $[1,2,3,4,5,6,7$, etc. $]$.

It should be noted that in scientific works a significant role is assigned to the cluster approach, which is used both in the process of developing strategies or models for sustainable development of territories, and in evaluating the results obtained during the development of individual regions [4,5,6, etc.]. It is noted that the development of territories can also be assessed using the human development index [7, 8, etc.], which, according to the World Bank in 2018, was the highest in Singapore (0.88), South Korea and Japan are in second place, while Russia is still only in 34th place in the global ranking (0.73). If we analyze individual indicators included in the integral index, then Russia is in the group of leading countries in terms of the quality of education (538 pp.). For example, Norway has this indicator-512, and the United States - 523. The survival rate of the adult population of 0.78 has a 
negative impact on the final index of Russia, which corresponds to only the 122nd place in the world, approximately on a par with Afghanistan, while, for example, Norway has this indicator -0.94 , and the United States - 0.9 [9]. Thus, we come to the conclusion that the education system significantly affects the development of the territory. At the same time, in Russia, the role of higher education is associated with the formation of such a volume of knowledge and a level of competence that will create employment opportunities for graduates [10]. Therefore, thanks to the formation of regional scientific and educational clusters, it becomes possible not only to train specialists for the needs of regions, but also to conduct scientific research for the requests of specific enterprises, thereby ensuring their technological development [11].

Thus, within the framework of this study, the tasks are set to identify the prerequisites for the creation of scientific and educational clusters in Russian regions and make a forecast regarding their impact on the sustainable development of territories.

\section{METHODS OF ASSESSING THE IMPACT OF THE HIGHER EDUCATION AND SCIENCE SYSTEM ON THE SUSTAINABLE DEVELOPMENT OF TERRITORIES}

To assess the impact of the higher education and science system on the sustainable development of territories, we will use the method of indicators. The number of higher educational institutions, scientific organizations, the number of students enrolled in higher education programs, the effectiveness of scientific research and their implementation in the activities of enterprises in the region will be considered as indicators.

The effectiveness of the activities of scientific and educational clusters can also be assessed with the help of a target system of global indicators that allows achieving the Sustainable Development Goals in accordance with the "Agenda for Sustainable Development for the period up to 2030". This system identifies the eighth goal, which involves "promoting sustained, inclusive and sustainable economic growth, full and productive employment and decent work for all" and the ninth goal "creating a stable infrastructure, promoting inclusive and sustainable industrialization and innovation". These two goals can be directly linked to the functioning of scientific and educational clusters, which are designed to promote effective employment in the regions and their innovative development.

The data of official statistics, the results of applied research related to the development of territories and higher education systems serve as the information base of the conducted research.

\section{THE RESULTS OF THE STUDY ON THE ASSESSMENT OF THE IMPACT OF THE SYSTEM OF HIGHER EDUCATION AND SCIENCE ON THE SUSTAINABLE DEVELOPMENT OF TERRITORIES}

It is impossible to imagine the sustainable development of territories in modern conditions without creating an infrastructure that will promote "sustainable industrialization and innovation". To assess the infrastructure, it is necessary to analyse the general and regional structure of the higher education and science system and its effectiveness. As of 2019, the higher education system in Russia is represented by 724 organizations, including $70 \%$ state-owned. There are about 4 million students enrolled in higher education programs (bachelor's degree, specialty, master's degree). with a total population aged from 20 to 24 years, about 7 million people. More than 46 thousand educational programs are being implemented. At the same time, scientific research in Russia is carried out not only on the basis of research institutes (research institutes) and design organizations, but also increasingly on the basis of universities that, according to the results of the tenth annual rating of the best universities in Russia RAEX100 in 2021, have significant progress in the field of scientific publications.

In the regional context, the researchers propose to structure the existing higher education systems, taking into account their potential and orientation, as follows:

- regional higher education systems with leading universities (16 regions, including Moscow and the Moscow region, St. Petersburg, Sverdlovsk Region, they are also the leading regions in socio-economic development);

- regions with a balanced system of higher education with an infrastructure orientation (15 regions, including "problematic" ones, for example, the Kurgan Region and "regions of special attention", for example, the Chechen Republic, from the point of view of socio-economic development);

- regions with a balanced regional system of higher education of an industry orientation (32 regions, mostly regions with growth points, for example, the Kaliningrad region, and clear prospects for socioeconomic development, for example, the Smolensk Region);

- regions with a predominance of infrastructure universities that act as monopolists, while there is an outflow of applicants (12 regions, most of which have uncertain prospects and problems of socio- 
economic development, for example, the Vladimir Region and the Republic of Kalmykia);

- "underdeveloped" regional higher education systems, characterized by signs of inefficiency, universities operating in a monopoly market and the maximum outflow of applicants from the region (8 regions whose socio-economic development is assessed as "problematic", for example, the Amur Region, and "special attention", for example, the Kamchatka Territory) [12].

Thus, the thesis is confirmed that the socioeconomic development of the territory also depends on the existing educational and scientific infrastructure in the region. Moreover, the results obtained when comparing the level of development of the higher education system and the state of socio-economic development of the region allow us to conclude that those regions that occupy leading positions in socioeconomic development should focus on the development of applied research and educational centers. And regions with lower indicators in the ratings for socio-economic development, but with a higher standard of living, should focus on the development of fundamental research and educational centers [13]. It is important to keep in mind that it is also necessary to ensure the retention of specialists trained by them in the regions, to establish communication between universities and enterprises interested in innovations.

With regard to the readiness of enterprises to engage in research work, it can be noted as positive points that over the period from 2000 to 2019, the number of industrial enterprises that have their own scientific divisions in Russia increased 1.6 times: from 284 to 450 , while over the same period the number of pilot plants increased slightly from 33 to 44 [14].

The sustainable development of the territories should be characterized by progressive sustainable economic growth, full and productive employment and decent work, but the effective use of labor in the economy remains a serious problem in the country. According to Rosstat, as of December 2020 (75.2), the number of workers decreased by 0.7 million people compared to December 2019 (75.9). The number of employees amounted to 70.8 million people, which is 1.6 million people less than in 2019. At the same time, the number of unemployed increased by 0.9 million people and amounted to 4.4 million. This indicates negative trends in the labor market, including those provoked by the pandemic. Thus, a significant part of the labor resources is unused in the Russian economy. In general, the employment rate of the population decreased compared to the previous year and amounted to $58.6 \%$ in December 2020, while the employment rate of men (66.3) is traditionally higher than that of women (52.2) by $14.1 \%$. And the employment rate in the city
(60.6) is higher than in rural areas (52.4) by $8.2 \%$. In 2020 , the registered unemployment rate increased 4 times compared to 2019 , amounting to $3.7 \%$ at the end of the year. In general, the unemployment rate was $5.9 \%$ as of December 2020, which is $1.3 \%$ higher compared to December 2019. The number of unemployed registered in employment services per 100 vacancies also increased by 3.2 times over the specified period. The growth was influenced by the situation with the pandemic and the Government's decision to increase the amount of unemployment benefits. In January 2021, this decision was extended, so the increased amount of the maximum unemployment benefit will remain for 2021 .

It is necessary to pay attention to the fact that the highest unemployment rate in October-December 2020 was recorded in the Republic of Ingushetia (31.2\%) and the Chechen Republic (21\%), followed by the Republic of Tyva (18.2\%), the Republic of Altai $(16.4 \%)$ and the Kabardino-Balkar Republic (16.1\%). At the same time, there are regions where the unemployment rate is lower than the average Russian level, so the lowest unemployment rate of $2.6 \%$ was recorded in the Yamalo-Nenets Autonomous Okrug, 3.2\% in the Khanty-Mansi and Chukotka Autonomous Okrugs, $3.5 \%$ in the Republic of Tatarstan and 3.6\% in Moscow. Thus, the employment situation in the regional context is also not homogeneous, and that is why it is necessary to take into account the specifics of the regions, in terms of the level of development of their scientific and educational systems and their inclusion in the regional agenda.

Thus, the prerequisites for the creation of scientific and educational clusters in Russian regions are, firstly, the presence of classical, research and branch universities and their research potential, the influx of young people to regional universities, the availability of jobs, the willingness of enterprises to cooperate with universities, not only in terms of training specialists, but also in the form of orders for research work.

Regarding the impact of scientific and educational clusters on the sustainable development of territories, we can say the following: if an effective network interaction is built, the region receives trained specialists for enterprises operating in this territory. Enterprises receive not only specialists, but also the opportunity to implement advanced developments formed under their order. Advanced technologies are designed to contribute to the efficient and competitive activities of enterprises in the region, as a result, tax deductions, decent income for employees and high-tech jobs.

At the same time, the system of indicators for assessing the impact should include: the share of university graduates who remain in the region and have the opportunity to find a job in their specialty, the 
number of scientific developments prepared by universities and implemented by enterprises in the region, as well as the share of high-tech jobs created in the region thanks to the cooperation of regional structures within scientific and educational clusters.

In general, we can say that the system of higher education and science in Russia through the formation of regional scientific and educational clusters will be able to contribute to the implementation of the Sustainable Development Goals. The difficulties in assessing the achievement of these goals are primarily related to the need to organize the systematic collection of statistical data in dynamics and in the regional context.

\section{CONCLUSIONS}

1. The sustainable development of territories is directly related to infrastructure, which should promote "sustainable industrialization and innovation" at the regional level, as well as "sustainable economic growth, full and productive employment, decent work for all" who live within a certain territory. According to the study, it is possible to implement this through the formation of scientific and educational clusters in the regions. Mutually beneficial cooperation should be built within these institutions, providing a significant contribution to the development of the territory. This requires combining the efforts of regional authorities, educational and scientific organizations, and enterprises.

2. It should be noted as a negative factor, from the point of view of regional development, that in general in Russia there is a high concentration of organizations engaged in scientific research and development in the Central Federal District, where almost half of all Russian researchers work. At the same time, the developments of only twenty percent of research organizations have been implemented over the past 10 years, which is also not a good result, most of them were also prepared in Moscow. This indicates not only low scientific productivity, but also low readiness of enterprises to invest in innovations. There is also a migration of highly qualified specialists from the regions to the centre of Russia and the cities of millions, which also reduces the opportunities for the development of territories.

3. The Russian higher education system is currently focused on research activities that can contribute to the innovative development of enterprises in the region through not only the introduction of developments, but also the training of specialists familiar with advanced technologies. This requires network interaction within the region between universities and the industrial sector of the economy on the basis of the creation and functioning of scientific and educational clusters. To do this, it is necessary to intensify work in the regions on the formation of these associations with the support of regional authorities. And for a dynamic assessment of the impact of scientific and educational clusters on the development of regions, it is necessary to organize a systematic data collection within a given system of indicators.

\section{REFERENCES}

[1] E.V. Bagirova, Ensuring sustainable development of rural territories as a factor of agricultural development. In: Bulletin of the Kemerovo State Agricultural Institute, 6 (2016) pp. 127-131.

[2] K. Yu. Vafina, A.O. Gabrielov, Program management of territories of advanced socioeconomic development (TOSER) from the perspective of the concept of sustainable development, Research and development. In: Russian Journal of Project Management, 1 (2019) pp. 3-15.

[3] R.R. Galiev, Project for the development of agricultural production and sustainable development of rural areas in the region, Ufa Humanitarian Scientific Forum, 2 (2020) pp. 6874.

[4] E.V. Zhertovskaya, M.V. Yakimenko, Development of a cognitive model for the development of a tourist and recreational complex of the territory focused on sustainable and innovative development: a cluster approach. In: Tourism: law and economics, 4 (2019) pp. 8-12.

[5] O.P. Ivanova, Assessment of the sustainable development of clusters in the territory of advanced socio-economic development of a single-industry city. In: National interests: priorities and security, 6 (2018) pp. 988-1004.

[6] E.V. Stovba, A.V. Stovba, A.S. Usmanov, A.G. Sharafutdinov, I.V. Araslanbaev, Using cluster approach and foresight technologies when designing a sustainable areas development strategy, SHS WEB OF CONFERENCES. In: Sustainable Development of Regions 2020 - XVI International Scientific and Practical Conference "State. Politics. Society" (2021).

[7] T.I. Alunova, Human development index as an indicator of sustainable development of the territory. In: Regulation of sustainable development of the regional economy, pp. 117-124 (2016). 
[8] S.I. Sotnikova, L.G. Milyaeva, O.L. Chulanova, Yu. A. Masalova, E. M. Mikhailova, Personnel competitiveness management based on the PERFORMANCE MANAGEMENT concept, NSUEM, Novosibirsk, pp. 223-230 (2020).

[9] Human Capital Index. http://platformaxxi.org.

[10] Y. Masalova, Sustainable education in Russia. In: E3S Web of Conferences, 1 (2020).

[11] Yu.A. Masalova, The use of human resources within scientific and educational clusters. In: Topical issues of personnel management and labor economics: materials of the VII scientific and practical conference, pp. 162-166 (2021).

[12] O.V. Leshukov, M.A. Lisyutkin, Management of regional higher education systems in Russia: possible approaches. In: University management: practice and analysis, 6 (2015) pp. 29-40.

[13] V.I. Bazhenova, A.E. Sudakova, I.A. Gurban, Regional systems of higher education of the Russian Federation: results of reform and management efficiency. In: Bulletin of the Plekhanov REA, 6 (2017) pp. 163-175.

[14] S. V. Saltanova, Science of Russia in 10 figures, https://issek.hse.ru. 